\title{
YrJö HaIla
}

\section{Pöllöjen hämärät}

\author{
LE N N O T : \\ TEE 20 VUOTTA
}

Tutkijaliitto perustettiin Koiton talon painisalissa tammikuussa 1976. Eräs liiton tärkeimmistä toimenpiteistä sekä tuonaikaisten suunnitelmien mukaan että jälkikäteen arvioituna oli perustaa monitieteinen aikakauslehti Tiede $\varepsilon$ edistys. Ensimmäinen näytelehti oli kesällä 1976 julkaistu tabloidimuotoinen tiedepolitiikkanumero, jossa käsiteltiin ns. Tandem -keskustelua. Ensimmäinen varsinainen numero ilmestyi syksyllä 1976, ja vuodesta 1977 lähtien vuosikerta on käsittänyt normaalit neljä numeroa.

Koiton talo? - Raittiusyhdistys Koiton hallinnassa ollut jugend-vaikutteinen kivirakennus Yrjönkadun ja Simonkadun kulmassa, eräässä Helsingin keskeisimmistä kortteleista. 70-luvulla talon toimistosiivessä majailivat mm. SKDL:n keskustoimisto sekä SKP:n Uudenmaan piirijärjestö. Painisali? - Koiton talon ydin oli juhlasali, joka 70-luvulla oli Helsingin keskustan tärkeitä teatteri- ja konserttipaikkoja. Juhlasalin yläpuolella oli useassa kerroksessa kokoustiloja, niistä ylin, räystään alla sijainnut kaltevakattoinen huone tunnettiin syystä tai toisesta nimellä "painisali" - arvattavasti se oli aiempina aikoina palvellut Helsingin Jyryn paininharrastajien harjoittelutilana.

Kukaan meistä paikallaolijoista ei olisi arvannut, miltä Koiton talo näyttää 20 vuotta myöhemmin. Harva olisi kaiketi myöskään arvannut, miltä $t \xi e$ näyttää 20 vuotta myöhemmin.

Hans-Jørgen Schanz toteaa hienon kirjansa Karl Marxin teoria muurin murtumisen jälkeen esipuheessa seuraavasti: "Yhtä vähän minä kuin kukaan muukaan olen tiennyt, minne ajatteluni minua vie. Kukaan niin kutsuttua perustutkimusta harjoittava ei tiedä, minne hänen tiensä kulkee."

Schanz ilmaisee tärkeän piirteen myös tEe:n historiasta. Lehden kehitys on ollut itseohjautuvaa samassa mielessä kuin teoreettinen tutkimus. Tieteellisen lehden tekeminen nojautuu tutkimukseen, tai lehti lakkaa pian olemasta tieteellinen.

Mutta tietenkään teoreettinen tutkimus ei ollut $t \xi e: n$ perustamisen ainoa peruste. Oli myös poliittinen motivaatio. Schanzin kirjan myötä korostuu se merkillinen kontrasti, joka vallitsi 70-luvulla Suomen ja jokseenkin kaikkien muiden Euroopan 
maiden välillä: toisin kuin muualla, Suomen marxilainen tutkijaliike oli alkuvaiheissaan ideologisesti tiiviissä yhteydessä puoluemarxilaisuuteen, vieläpä SKP:n vasemmisto-oppositioon, joka oli Neuvostoliiton kommunistisen puolueen kanssa täydellisessä ideologisessa ja poliittisessa yhteisymmärryksessä. Tämä selittää, että Tutkijaliitto perustettiin Koiton talossa, jolla on kunniakas vuosisadan alkuun ulottuva historia Helsingin vasemmistolaisen työväenliikkeen tukikohtana mutta ei mitään erityisempiä siteitä akateemiseen maailmaan. Ideologisen puolueyhteyden ymmärtäminen jälkikäteen on vaikeaa, osittain siksi, että asiantilan muisteleminen ei ole miellyttävää. Nykypäivän näkökulmasta osa meistä oli tässä suhteessa järkyttävän sokeita.

Mikä on selitys? En usko, että selitystä pystytään vielä antamaan. Minervan pöllö ei ole vielä lähtenyt lentoon. Suomen akateemisen marxismin puoluesolidaarisuuden selittäminen edellyttää sellaista maamme 1900-luvun poliittisen historian analyysiä, joka on vielä tekemättä. Olemme hädin tuskin kansalaissodassa asti, vastahan esimerkiksi Heikki Ylikankaan Tie Tampereelle ja Risto Alapuron Suomen synty paikallisena ilmiönä 1890-1933 ilmestyivät muutama vuosi sitten. Sitä paitsi Ylikankaan ja Alapuron kirjojen laimea vastaanotto ei lainkaan tue kuvitelmaa, että niiden tuloksia yleisesti sovellettaisiin kansalaissodan jälkeen syntyneen Suomen historian tulkintaan.

Sanalla sanoen, en mitenkään kykene kuvittelemaan, että Suomen yliopistomaailman intellektuaalinen tilanne 60-70-lukujen vaihteessa olisi ymmärrettävissä ilman kansalaissodasta ja sen luomasta "ensimmäisestä tasavallasta" lähtevää poliittista ja kulttuurista taustaa. Eräs keskeinen tekijä on Suomen liberaalin perinteen ohuus. Akateeminen Suomi ei tarjonnut radikaalille ajattelulle muita tukipisteitä kuin vähäiset vasemmistolaisen työväenliikkeen ympärille ryhmittyneet, marginaaliin ahdistetut piirit. Vahvoja ja itsenäisiä liberaaleja on toki ollut suomenruotsalaisen sivistyneistön piirissä, mutta nämä ovat myös olleet marginaalissa vaikkakin eri syistä kuin vasemmistolainen työväenliike.

SKP:n vasemmistolainen oppositio eli "taistolaiset" edusti 70-luvun alussa utooppista vaihtoehtoa, joka näytti nojautuvan teoreettisesti kunnianhimoiseen kriittiseen ajatteluun. Vasta vuosikymmenen loppua kohden paljastui, että teoreettinen kriittisyys oli näennäistä ja nojautui Neuvostoliitossa kehitettyyn, niin kutsuttua sosialistista taloutta legitimoivaan käsitteiden helinään. Muualla Euroopassa, Schanzin sanoin (s. 80), "Marxin teoria vapautettiin 'marxismin historian' kuonasta" jo 60-luvulla, Suomessa sen sijaan vasta 70-luvun loppupuolella. Tosin tämän asian suhteen jotkut keskuudessamme olivat paljon terävänäköisempiä kuin useimmat muut.

Asetelmaan liittyy vielä eräs laajakantoisempi moraalifilosofinen kysymys, jonka "muurin murtuminen" on nostanut näkösälle: onko mahdollista, että oikeutettuun vastarintaan nousseet sorretut kansanjoukot ovat olleet väärässä? Vastasimme tähän 20 vuotta sitten empimättä kieltävästi, ja tämä tuotti meille moraalisen velvoitteen asettua ehdottomasti hävinneiden puolelle. Arvelisin, että Suomen lähihistorian peiteltyjen vääryyksien paino on ollut ja on edelleen olennainen meitä esimerkiksi muista Pohjoismaista erottava tekijä.

Historia on kuitenkin viekkaampi, kuten jo Ranskan vallankumousta seurannut terrori osoitti niille, jotka asian ymmärsivät; tästähän esimerkiksi Viikarin Matti meitä toistuvasti muistutti. Emme siis enää tiedä kysymykseen vastausta. Tai pikemminkin olemme jo kauan epäilleet, että kysymys on väärin esitetty. Asettua ehdottomasti puolelle tai toiselle ei ole ratkaisu vaan osa ongelmaa. Ehdoton 
puolueellisuus vain lisää vaaraa, että toisiaan seuraavien tekojen armoton kierre riistäytyy lopullisesti hallinnasta. Alapuron Suomen synnyn tarina Huittisista kansalaissotaa edeltäviltä vuosilta tuo tämän tragiikan tavattoman selvästi esiin.

Politiikka vaikutti $t \xi e: n$ perustamiseen toisellakin tasolla. Tiedepoliittinen keskustelu oli 20 vuotta sitten paljon kärkevämpää kuin nykyisin - näiltä osin tEe:n ensimmäisten vuosikertojen selailu on kuin ajaisi aikakoneella mammuttien maailmaan. Vuonna 1976 keskustelua hallitsi Tandem eli Suomen Akatemian rahoittama tutkimushanke "Tasa-arvon ja demokratian tutkimusprojekti". Lempinimellä "kanslerisäätiö" tunnettu Korkeakoulu- ja tiedepoliittinen tutkimussäätiö nosti projektia vastaan voimakkaan julkisen kritiikin väittäen sen olevan poliittisesti motivoitua "nollatutkimusta". Tiedekeskustelun "politisoituminen" oli akateemisen maailman konservatiivisten piirien aikaansaannos, järkyttävä ylireaktio siihen, että Akatemia rahoitti vähäisessä määrin vasemmistolaisittain ja jopa marxilaisittain suuntautunutta yhteiskuntatutkimusta.

Tandem-kiistaa edelsi häly Akatemian rahoittamasta ns. Meteli -projektista, jossa selvitettiin metalliteollisuuden työolosuhteita. Se, että työolot todettiin stressaaviksi ja työturvallisuus puutteelliseksi, antoi joillekin aiheen leimata tutkimus puolueelliseksi ja epätieteelliseksi.

TEe käsitteli parin ensimmäisen vuoden aikana toistuvasti tiedekiistoja ja mm. kommentoi Tandem-projektin loppuraporttia vastaan käynistettyjä hyökkäyksiä. Numeron 1/77 Tieteellinen elämä -palsta esimerkiksi sisälsi uutisen "Suomen tiedepoliittiset pyövelit teroittavat kirveitään odotellessaan uhrinsa, TANDEMprojektin loppuraportin valmistumista". Aikakauden tiedepolitiikan tunnelmista antaa kattavamman kuvan numerossa 1/77 julkaistu Kettil Bruunin haastattelu "Kokemuksia 70-luvun tiedepolitiikasta".

Oli miten oli, tEe on täällä tänään. Ns. taistolaisen liikkeen solidaarisuustilaajien turvin $t \xi e$ vakiinnutti asemansa taloudellisesti. Alkuvuosien tilauskanta oli parin tuhannen tienoilla, mikä riitti mainiosti sekä lehden että Tutkijaliiton toimiston kulujen kattamiseen. Akatemian tukea tॄe alkoi saada vasta myöhemmin.

Lehden sisältö oli alusta alkaen tutkimuksellinen ja alkoi seurailla Schanzin toteamia latuja, siis ei mitään ennalta merkittyjä latuja lainkaan. Puoluemarxilaiset teemat hävisivät kokonaan - tämän päivän näkökulmasta sanoisin: yllättävän ja ilahduttavan nopeasti. Etusijalle nousi uusien teoreettisten keskustelujen esittely, aluksi etenkin marxilaisten, mutta myöhemmin laajassa mielessä edistyksellisten ja sittemmin yleensä intellektuaalisesti kiinnostavien ja korkeatasoisten. Kerran toisensa jälkeen $t \xi e$ on osoittanut, että ennakkoluulot kannattaa työntää syrjään ja tutustua kirjoittajiin, jotka suhtautuvat asioihin totutusta poikkeavalla tavalla. Tähän luetteloon mahtuvat Jürgen Habermas, Michel Foucault, Richard Rorty, Jacques Derrida, Ulrich Beck, Gilles Deleuze... Siis monet tutkijat, joiden tuotanto on tänä päivänä kirjahyllyissämme keskeisimmillä sijoilla; tuntuu itse asiassa merkilliseltä, että vasta äskettäin on ollut aika, jolloin heitä ei Suomessa tunnettu juuri lainkaan. - Vai tunnetaanko oikeastaan vieläkään? Ainakin minä tunnen huimausta joka kerran käydessäni Ruotsissa ja huomatessani, kuinka suuri määrä "moderneja klassikoita" naapurimaassamme on tarjolla kotikielelle käännettynä. Tästä seikasta tEe:n Tieteellinen elämä on vuosien mittaan useasti huomauttanut.

Näkökulmien jatkuva uusiutuminen on oma kiinnitykseni $t \xi e$ :hen: lehti on monia virtoja yhteen kokoava pyörre, jota pitää koossa intellektuaalinen kiinnostus jännittäviä asioita kohtaan. Monitieteisyys on olennaista. Uskaltaisin melkein korottaa seuraavan kokemuksen yleispäteväksi: oivalluksia voi parhaiten saada 
lukiessaan älykkäitä tekstejä oman varsinaisen alansa sivulta. Mutta eklektisen lukijan keskeinen ongelma on tietenkin kyetä erottamaan toisistaan yksityisajattelu ja vakava ajattelu. Kenenkään oma intuitio ei voi tähän riittää. Monia tieteenaloja kattavan lehden on erityisen tärkeää olla tarkka aineistonsa tasosta. Tässä suhteessa esimerkiksi Alan Sokal -historia on todella valitettava eikä Social Text -lehden kannalta laisinkaan mairitteleva.

Mitä alkuperäisestä $t \in e$ :stä on jäljellä? - Ensimmäisen toimituskunnan jäseniä on nykyisessä toimituksessa kolme. Yksi heistä, Arto Noro, on kuulunut toimitukseen koko ajan. Kirjoittajakunta on vaihtunut lähes täysin. Kahdessa ensimmäisessä täydellisessä vuosikerrassa, 1977-78, esiintyi haastattelut mukaan lukien 78 suomalaista kirjoittajaa, ja kahdessa viimeisimmässä täydellisessä vuosikerrassa, 1994-95, 81 kirjoittajaa. Näistä kuusi on samoja.

Entä onko alkuperäinen idea ennallaan? - Millä "ideoita" mitataan? Miten voi tunnistaa "idean" säilyneen ennallaan tai muuttuneen toiseksi? Tietyissä suhteissa $t \mathcal{E} e: n$ idea on ennallaan (nojautuminen teoreettiseen perustutkimukseen), tietyissä suhteissa se on alusta lähtien ollut jatkuvassa muutoksessa (uusien näkökulmien etsintä), ja joku osa alkuperäisestä ideasta on kauan sitten hylätty (ideologinen sidonnaisuus). Lehden tekemistä motivoivan idean kantavuutta koetamme jatkuvasti arvioida - pohjoisten pöllöjen turvin (Ukuli, vuonna 1979 perustettu Tutkijaliiton jäsenlehti, on saanut nimensä Aleksis Kiveltä). Pohjoiset pöllöt joutuvat mukautumaan paikallisiin olosuhteisiin ja esimerkiksi lentämään kesäaikaan auringonpaisteessa, koska aurinko paistaa pohjoisessa kesäisin läpi yön. Hegelin Minervan pöllö, etelän viinimaiden asukki, voi sen sijaan ylellisesti säästää lentoonlähtönsä siksi kunnes hämärä laskeutuu.

Ukuli ja muut pohjoiset pöllöt varmasti toivottavat $t \xi e: l l e ~ s e u r a a v i k s i ~ k a h d e k s i$ vuosikymmeneksi samaa hyvää ja ennakoimatonta kulkua, jota ensimmäiset kaksi vuosikymmentä ovat olleet. Ei kuitenkaan ole aivan varmaa, onko oikea Minervan pöllö jo noussut siivilleen... 